\title{
Teachers' opinions on implementing educational standards in Serbia and Croatia
}

\author{
Aleksandra S. Maksimović ${ }^{1}$ \\ College for Early Years Education and Care, Šabac, Serbia \\ Ivana Ćosić \\ Zagreb, Croatia
}

\begin{abstract}
The aim of the paper is to compare the way in which the concept of educational standards and its introduction into educational policy and school practice is perceived by teachers from Serbia and teachers from Croatia. The paper also investigates teachers' perspectives on educational standards in the Croatian and Serbian primary and secondary education and contrasts them with the understanding of standards elsewhere. A qualitative methodological approach was applied in conducting the interviews and focus groups with teachers, accompanied by a thematic analysis of the collected data. The interviews and focus groups were carried out as a part of research within two $\mathrm{PhD}$ theses. The sample consisted of 101 teachers, out of whom 57 were primary school teachers from Serbia and 44 were secondary school teachers from Croatia. The results show that teachers from these countries have very similar perspectives on the implementation of educational standards in their respective countries. The findings are presented within three connected themes: 1) distrust in the educational administration; 2) thinking about education as a public good, and 3) standards as the ways of overcoming some shortfalls in professional identity.
\end{abstract}

Keywords: educational standards, teachers, Serbia, Croatia

\section{Introduction}

Over the past forty years, the number of countries that embraced measuring students' learning based on a priori defined standards and outcomes has been on constant increase (Barber, 2004; Hursh, 2005; Smith, Anderson \& Blanch, 2016; Volante \& Earl, 2015). Educational outcomes and standards represent a way of thinking about teaching and learning based on clearly stated expectations on what should be learned and when. Usually, the 'what' of learning is then tested via standardized, nation-wide tests. The test

1 aleksandramaksimovic82@gmail.com 
results are meant to show the 'what' of achievement - both for the teachers and students - against the previously agreed learning outcomes as determined by the curriculum. In terms of education policy, this is a way of increasing accountability for teaching and learning: teaching is no longer a 'black box' (Black \&Wiliam, 1998), but a more transparent, unambiguous process. Setting learning goals in the form of outcomes and standards and comparing test results give a sense of knowing how the classroom teaching and learning are going. Parents and policy makers are particularly interested in knowing how students achieved the learning outcomes that had been set in advance. This way of managing teaching and learning integrates an executive mindset with education: the inputs, that is, the learning standards are firmly set, while the outputs, the achieved results, should encourage more reflection on the part of the teacher and the student about the ways of making improvements (cf. Hargreaves et al, 2001).

Epistemologically, standards are rooted in a behaviourist, positivist perspective towards learning. This means there is an expectation that there would be a procedure that could measure learning objectively (e.g. Berry \& Adamson, 2011; Broadfoot, 1996; Wyatt-Smith \& Cumming, 2009). Furthermore, learning is seen as an incremental occurrence, which linearly reflects students' development. Still, most theories about learning, for example, those rooted in social constructivism (cf. Vygotsky, 1977), or cognitive theory (cf. Bloom et al., 1956), do not necessarily conceptualize learning as a process in linear increments towards a previously defined goal. Instead, they place things such as context, learning purpose, human relationships and feelings at the centre of their understanding of learning. Such approaches to learning seem to increasingly identify learning as an interactive, open, transformative and creative process that should prepare learners to act in unpredictable situations in the future, rather than replicate the 'right' procedures (Stobart, 2008). It can thus be said that managerial standards in education and the ideas about how learning works envision learning from completely different paradigmatic positions. In other words, there is no full overlap between what the standards want to achieve and what learning science believes that learning is (Broadfoot, 1996).

Although educational standards have an origin in positivist epistemology and a behavioural approach to learning, they get implanted in a cultural context where realities are negotiated and constantly built and rebuilt. The origins of educational outcomes and standards can be found in the USA of the cold war, where outcomes were thought out as a strategy to improve education and bring progress (Spady, 1998). In the educational literature, outcomes are generally understood as something that is more vague and interpretive than standards, whereas standards are understood to be more directive and generally easier to measure by standardized tests (Hargreaves et al., 2001). In practice, however, this distinction is not clear-cut - the terms outcomes 
and standards are sometimes used interchangeably in policy and research, depending on the country and context. For example, Sharma says that in the USA standards are the expected achievements at a specific level, whereas in Canada the term standards represents a set of "prescribed learning outcomes defined as statements about what students are expected to know and do at the end of the indicated grade or course" (Sharma, 2015, p. 16). In Germany, standards are defined as "obligatory requirements for teaching and learning in schools. [...] They prescribe which competences pupils should attain at the end school years" (Klieme et al., 2003, p. 9). This goes to show that standards can be understood both as absolutely mandatory and as recommendations, depending on the educational context. Nevertheless, both standards and outcomes underline the thinking that it is important to (a) set educational goals and (b) measure student's achievement of those goals in a certain way.

Generally, standards are linked to standardized tests. The way in which standards are understood is usually related to the stakes attached to them. In some educational contexts, achieving standards is absolutely mandatory and there are sanctions for students, teachers and schools for not achieving them. Equally, there are rewards if standards are achieved. In other settings, standards serve as relatively liberally interpretative recommendations that guide learning and teaching. Whilst standards and outcomes may mean different things across different educational contexts, a lot has been written about the possible consequences of standards and outcomes for education.

The change in thinking about teaching and learning brought on by standards and outcomes has allowed significant modifications in the way in which schools are organized and the way in which teachers enact their professional identity (Ball, 2015). It has also influenced how learners define themselves (Reay, 2012). Standards, particularly those measured by organizations such as the OECD, have influenced the policies of many educational systems and are believed to increasingly do so today (Rizvi\&Lingard, 2010). By making learning more manifest and more concrete, outcomes have opened up a space for teachers, schools and students to compare their results and to compete. Competition and comparison have, in turn, contributed to an understanding of education as a commodity, as something that can be acquired and traded (Ball, 2015).

It has been argued that standards and outcomes have shaped the way in which we think and speak about education. Although they look different depending on the context in which they exist, it is believed that they are instruments of the neoliberal wave that has swept educational settings across the world (Rizvi\&Lingard, 2010).

In the literature on comparative education, there are those who think that all the countries will follow a linear developmental trajectory in adapting the borrowed educational reforms. This means that the trajectory would closely 
resemble the one taken by the countries that have already been through the process (e.g. the World Culture Theory). However, the researchers in the field of post-socialist education have a different opinion (cf. Silova, Steiner Khamsi, 2008). Silova and Steiner Khamsi (2008) have shown that globally travelling policy packages (including standards, decentralization and childcentred learning) take completely different shapes in different contexts, sometimes to the extent that their meaning gets completely changed. By analysing three case studies, Kazakhstan, Tajikistan and Turkmenistan, Silova (2005) has shown that post-socialist countries tend to accept the discourses of the international community, for example, on the curriculum, gender equity, or academic freedom, but that they use those discourses not to reform but to perpetuate the existing values on schooling, gender and academic freedom. In other words, international policies get 'hijacked' and reused for local purposes, without essentially changing education in the ways initially intended.

In terms of standards, Minina (2014) has pointed out to the inconsistent pairing of neoliberalism and standards in post-socialist settings. In her paper, Minina presented a case study of implementing educational standards in Russia, covering the period from 1991 to 2011, and using five sets of data: 1) the official government statements and law; 2) public statements; 3) polling agencies' sociological data, 4) public discussions and 5) media reporting about educational issues. Her research showed the importance of recognizing and taking into account cultural distinctions as a major element in the process of every social reform, including the educational reform. The author explains that "global travelling policies undergo processes of cultural policy interpretation by grassroots stakeholders, producing local conceptualizations that may be radically different from the intended ones" (Minina, 2014: 39). We draw upon this line of thinking and expand it to analyse the context of implementing educational standards in the case of Croatia and Serbia. In particular, we are interested in the influence of the administrative apparatus on the understanding of standards.

Although there is a dearth of educational arrangements across the world into which standards have been introduced, there seems to be a persuasive argument that in any of those cases, we are going to see education changed to fit neoliberal technologies. It is as if standards and outcomes change education only in one specific way. We maintain that the Croatian and Serbian examples show that the changes can be diverse and that responses can be unexpected. In light of this, we wanted to explore how the Serbian and Croatian teachers understood the notion of standards within their context, which is predominantly one of public education. This leads to the focus on outcomes, an increasing degradation of the idea of a public good, and an orientation towards education as a personal property, with standards as the currency. 


\section{Serbia and Croatia - historically and now}

Croatia and Serbia used to be parts of the same Eastern European country between 1918 and 1991. Today, Croatia has about 4.3 million citizens and covers 56,594 square kilometres; Serbia has about 7 million citizens and 88,361 square kilometres. According to the World Bank statistics, Croatia is ranked $55^{\text {th }}$ and Serbia $89^{\text {th }}$ among 183 countries whose data are available when GNI (gross national income) per capita on Atlas methodology is analysed (World Bank, 2017). When it comes to the Human Development Index, Croatia holds the $46^{\text {th }}$ and Serbia the $67^{\text {th }}$ place among 189 countries covered by international ranking (HDI Index 2018). In terms of the political, economic, and social specificities, the main difference between the two countries is that Croatia has been part of the EU since July 2013, while Serbia is in the accession process, with a plan to integrate into the EU at some point in the future.

Because of the shared history, education in Croatia and Serbia is structurally similar. It can be divided into four cycles: pre-primary, primary, secondary and tertiary levels. Pre-primary education includes children from six months to six and a half or seven years of age. Primary education is compulsory until the age of 15. After compulsory education, at the secondary level, the distinction is made between academic and vocational education. At this point, students can choose to attend either the Grammar School/Gymnasium (four grades from age 15 to 19) or some of the vocational (technical, industrial, craft) or artistic (dance, music, art) education schools which last for three or four years. After the completion of secondary education, students can start education at the tertiary level choosing between high schools of applied studies (3 years) and university (Graduate 4-6 years, Master of 1 or 2 years and $\mathrm{PhD}$ level, 3 years).

The long common history resulted in the fact that besides the administrative apparatus, the values shared in socialism can also still be observed today in these educational systems. One of them is humanism in pedagogy that reflects the idea that teachers should help their students to develop themselves into "complete humans" and to preserve their identity diverse in the comparison with the peers from the Western countries (Dull, 2012). In this context, some scholars wrote about "Slavic humanism" that distinguishes the students from alienation and materialism of the citizens of the more developed countries and that should be developed through schooling (Dull, 2012: 512, 528; Sobe, 2008: 76,117).

Although the two countries used to share some educational features in socialism and still have a similar educational structure, each had an independent educational programme. After the wars that led to the break-up of Yugoslavia, each country strived to find its own cultural identity adopting 
the globally 'travelling' neoliberal ideas: participation in PISA, increase in the number of university graduates, adoption of standards and more 'objective' and transparent ways of evaluating learning.

Croatia. It could be said that Croatia has introduced some aspects of the 'standards' thinking, albeit it has not yet organized its educational administration and thinking around them as some other countries. For example, after signing up to receiving a World Bank loan in the early 2000s, strategic documents in education emphasized a welcoming attitude towards standards, competencies, learning outcomes, human capital, and the knowledge economy. The first reform that underscored this attitude was the reform of primary and middle education (students aged 7 to 14). This reform was called the Croatian National Educational Standard (2006). Although the word 'standard' stands firmly in its name, the document itself does not contain standards - understood here as the descriptions of what students should be able to do or know by the end of a particular grade or the educational cycle. What the document does entail, however, is a general humanistic orientation towards teaching and learning. It describes the roles in school and justifies why particular subjects have been included and what they aim to achieve for the holistic development of a student. After that, learning outcomes for each subject are listed. For example, for the first grade, there are 27 topics (each belonging to one of five learning areas: (1) reading and writing; (2) language; (3) language expression; (4) literature and (5) media culture). Each topic has a number of learning outcomes, without the instructions on how those should be marked (MOSES, 2006, p. 26).

Serbia. For decades, the Serbian educational system has been criticized because it has been recognized as highly centralized (Rado, 2010; Radišić et al. 2012; Stanković, 2011). The curriculum has been criticized as well because of its extensiveness, generalization and abstraction (Dull 2012; Ivić, 1996; Kovač Cerović \& Levkov, 2002; Hebib \& Spasenović, 2011). Criticism of those practices, followed by under-average results on the international PISA and TIMSS surveys, as well as by the change of the political circumstances at the beginning of 2000s, resulted in a reform of the educational system. In this reform, for the first time in Serbia, the outcomes of learning have been outlined. In educational policy documents, outcomes have been presented as the most adequate way of connecting the processes of learning and assessing (Opšte osnove školskog programa, 2003). However, with another change of political authority, this approach was abandoned in 2004 and outcomes have been implemented since the school year 2018/2019 in the first (Sluzbeni Glasnik RS 10/2017 and 12/2018) and the fifth grade of primary school (Sluzbeni Glasnik RS 8/2018), and in the first year of general secondary education (Sluzbeni Glasnik, Prosvetni Glasnik, jul 2018, br. 12). 
The survey called Proposal of educational standards at the end of compulsory education (Radunović, 2007) started in 2005. Four years later, in May 2009,the National Education Council Republic of Serbia announced Educational standards for the end of compulsory education, which defined the expected students' learning outcomes at the end of the eighth grade of primary school, when studentsare15 years old (Zavod za vrednovanje kvaliteta obrazovanja i vaspitanja, 2009). The standards for the end of the first cycle of compulsory education, when students are completing the fourth grade of primary school and are11 years old, were defined in 2011 (Opšti standardi postignuća - obrazovni standardi za kraj prvog ciklusa obrazovanja, 2011). The standards of students' achievement for the end of general secondary education (Gymnasium) and general education subjects in secondary vocational education were created in 2013 (Pravilnik o opštim standardima postignuća za kraj opšteg srednjeg obrazovanja i srednjeg stručnog obrazovanja u delu opšteobrazovnih predmeta, 2013). With the intention of continuous monitoring and improving the quality of education, in June 2015, the standards for obligatory subjects in primary and in general secondary education were partially revised.

Educational standards in Serbia are defined as "statements about the basic knowledge and skills that students should acquire at a certain level of education" (Zavod za vrednovanje kvaliteta obrazovanja i vaspitanja, 2009, p. 6). In line with this, it has been emphasized that the crucial quality of implementing standards in educational policy and practice is that they are expressed in terms of measurable students' behaviour (Autor 1, 2016).

\section{Methodology}

The aim of this paper is to compare how the concept of educational standards and its introduction into educational policy and school practice are perceived by teachers in Serbia and Croatia. More precisely, the paper contrasts teachers' attitudes towards educational standards in the Croatian and Serbian primary and secondary education with the attitudes towards standards elsewhere. The data presented in the paper were collected as a part of empirical research conducted within two $\mathrm{PhD}$ theses. In one $\mathrm{PhD}$ survey, teachers from nine primary schools from Serbia participated in the research. This survey was conducted from February to September 2012. The technique of triangulation (Oliver-Hoyo \& Allen, 2006) was used in the research: the teachers first filled in the questionnaire and after that those who were interested in taking part in the next phase of the research came to an interview and brought along one of their lesson plans. A total of 290 teachers completed the questionnaire, 57 teachers were interviewed and 51 lesson plans were analysed. In this paper, only the data gathered during 
the interviews are used. The second $\mathrm{PhD}$ research was conducted in five secondary schools in Croatia: three vocational schools, a comprehensive school (with a mix of grammar and vocational curricula), and a grammar school. At different times during the school year, a total of twenty-seven focus group interviews and twenty-eight individual interviews were held. Interview participants were students, teachers, and head teachers from the selected schools. In this paper, only the data of 44 participating teachers and head teachers are used. The chosen schools varied in size, student intake, and location in an attempt to acknowledge the differences between schools in the country and to understand their varied responses.

In both countries, personal contacts were used in the process of getting access to schools and teachers. In Serbia, the first author contacted the school pedagogues and psychologists that were her acquaintances and who were interested in helping her to conduct research by introducing her with head teachers who should allow the conducting of research in schools and with the teachers who would like to participate. In Croatia, having received a recommendation of the Ministry of Education to conduct the research, the second author first tried cold calling secondary schools, but, to save time, she changed her strategy and contacted schools through personal contacts, electing participating schools to be different from one another.

Participation in interviews was voluntary and the interviews were semistructured, with a duration between 50 and 70 minutes both in Serbia and in Croatia. This decision was taken out of respect for teachers' time, but also to prevent selection and/or coercion into participation by head teachers. The participants were guaranteed confidentiality, and interviews were recorded and transcribed.

The data were analysed using a thematic analysis approach (Guest, MacQueen, \& Namey, 2012) and the method of constant comparison (Merriam, 1998). This meant going back and forth through the themes several times during the analysis until the main themes became more and more apparent. The data were analysed separately for Croatia and Serbia. After discussions on data analysis, the authors found similarities in teacher responses between the two contexts and decided to investigate this further, selecting relevant quotations from their studies and inter-relating them.

Although the data on teachers' perspectives on implementing the standards were similar across the two countries, a limitation is certainly that the data are a result of interview schedules that were different and of two empirical studies that pursued slightly different goals. Nevertheless, there are also methodological similarities: both used semi-structured interview schedules and dealt with teachers' perspectives on educational reforms, which were both rooted in the idea of standards. In both countries there 
were several key topics around which the interviews were organized. In Serbia, the author asked the teachers about their perception of the process of the implementation of the standards, whether there was compatibility between the standards and teaching plans and programmes and how that was reflected on their work, what the purpose of standards was and what kind of changes and consequences (if any) the standards introduction would have on teachers' work, teacher-student-parent relations, students' marks and the process of evaluation of teachers' work. In Croatia, the author focused on the following themes during the interviews: teachers' experience with the state matura, attitudes towards the matura tests, the purpose of the matura, the changes in students, the discussion of the benefits and disadvantages to external testing, and the links between exam results and teachers' work.

In addition, due to the fact that at the moment of the field research standards were implemented only in Serbian primary schools, the research in Serbia involved only the teachers from primary schools and the research in Croatia involved only the teachers from secondary schools. Also, one of the differences lies in the fact that, in Serbia, only individual interviews were conducted, while both the individual and the focus groups interviews were held in Croatia. Although this reflects the differences in the way in which the data were collected across the two contexts, which may be seen as a limitation, we argue that the similarities in the teachers' responses to the reforms rooted in standards form a good basis to make claims about the ways in which the respective educational contexts, particularly the (postsocialist) administrative apparatus and its tacit rules defined the space in which teachers reacted to the introduction of standards.

We want to emphasize that the results reported in this paper do not represent all teachers' opinions and practices regarding the implementing of educational standards in Croatia and Serbia. Still, they do provide some information about teachers' reactions related to the reforms of educational policies, and they build on a rising number of research studies examining the effects of standards-based education on teachers' thoughts and responses about the standards-based education.

\section{Results and discussion}

This section comprises three subsections related to the issues identified to explain the Croatian and Serbian teachers' responses to the introduction of reforms based on standards: 1) distrust in the educational administration, 2) thinking about education as a public good, and 3) standards as the ways of overcoming some shortfalls in professional identity. 


\section{Distrust in the educational administration}

Most respondents referred to the introduction of standards in Serbia and Croatia through the prism of the relationship with educational administration. Teachers resisted the changes, not because they did not believe in the reforms, but because they did not trust the people who were administering the changes to do something conducive to educational quality. In other words, teachers in both countries evaluated the reform not through its content and the possible changes it may bring, but based on their already formed preconceptions of the educational administration. Excerpts from the interviews given below demonstrate the teachers' perceptions of the educational administration and of the administration's stance towards education and teachers.

Why don't you ask a teacher who has been working for over 25 years? I was applying those standards before, too. Which means that I don't really see myself in some new story. I have been doing it this way forever. (Class teacher, 28 years of experience, Serbia)

It's just the terminology that has changed. Before it used to be goals and outcomes. Today we have standards. In a few years' time they will invent some other term. (Music Teacher, 8 years of experience, Serbia)

Similarly, in Croatia, the teachers saw changes through the prism of their relationship with administrators. In both cases, the teachers did not trust the administrators to know what good education was. Hence, any change would be difficult to implement from the get-go.

It is clear that the laws are drafted and passed by the people who aren't competent and don't know how the school functions. The problem is that they are at the top of the food chain, and it's us who carry the responsibility directly towards teachers and students. (Croatian language teacher, 8 years of experience, Croatia)

The system cannot be changed. It is set in stone. We have certain freedoms to move within the framework. But as far as the administrative side is concerned, there is little room to manoeuvre. We can't just say, 'this makes no sense, I don't want to do it'. I often speak against this, but I keep doing it because I don't have a choice. We have the freedom to speak and openly complain but nobody hears us. And, when they hear us, then they get very surprised - which planet did we fall off? (Croatian language teacher, 32 years of experience, Croatia)

Thus, it may be argued that with this respect the teachers were not afraid of performativity or anything new in the policy that could create a danger of undermining their professional identity. What defined teachers the most was their dependency on their distrust in the educational administration. Also, based on the attitudes of the teachers from the sample, it seems that a large portion of resistance had come from the increased amount of work imposed 
by reforms. It cannot be claimed that teachers saw standards as a threat or as something that would make their work more competitive and insecure. On the contrary, they seemed to understand standards as something that just added to the already existing bureaucracy. This result is in line with the findings of the research by Komlenović, Malinić and Stanišić (2014: 402), in which the majority of 400 examined teachers from primary schools in Serbia reported they were faced with too many administrative obligations related to standards, which took up a lot of their time. Similarly, Radišić et al. (2012) wrote that standards had been recognized as another administrative request by the majority of teachers in Serbia that took part in the RANON PROJECT (when five focus groups with 59 teachers were organized, investigating the topics related to the standards-based education). However, in our research, in no way did the teachers appear to be concerned that standards would fundamentally change their way of thinking about teaching and their students' learning. Teachers' answers addressed more the competency of administrators than the actual content of the policy. We believe that the reasons for those teacher perspectives lie in the changes in the education policy that were taking place in both countries - but without a sense of an active participation of teachers in creating the reforms (Autor 1, 2016; Pantić, Closs \& Ivošević, 2010; Pantić \& Čekić Marković, 2012; Pešikan, 2012; Radulović, Pejatović \& Vujisić Živković, 2010; Stanković et al., 2012; Stanković, Đerić \& Milin, $2013)$. For that reason, the teachers felt being inadequately respected by the administrators and responded by compartmentalising their classroom practice to the performance 'behind the closed classroom door' and their administrative performance for the public (Radišić et al., 2012: 230). In this research teachers positioned themselves as experts in pedagogy, as those who knew what was best for their students. On the other hand, the teachers saw administrators as those who brought innovations which teachers were already familiar with or as those who created contradictory regulations. Their main justification for the incompetence of administrators was the lack of consistency and 'being systemic' and the fact that teachers had more classroom experience. In this context, it is important to address the 'quality of teacher trainers', because teachers require well-trained and competent trainers that can transmit good practice and demonstrate how to be a good teacher (Stanković et al., 2013: 98).

\section{Thinking about education as a public good}

Teachers believed in public education, with the idea that there is a perfect procedure, both at the state and school level, which brings together teaching and learning. This can be seen in the expectation that all laws align perfectly - if this were not the case, then somebody else was to blame, not the teachers. We believe that the premise or the background behind this kind of reasoning is socialist. 
No, reforms were not settled in depth. We can talk about these things. I am still a young colleague, although I have ten years of experience. I am still young and ambitious but the situation at the teachers' meetings suggests that we cannot change anything. We are dealing with some interesting things, but those things actually do not matter. We have teacher meetings where something is said, sometimes it is more and sometimes less interesting, and systematic and professional things are not discussed. Practically everybody does what they think they need. (Croatian language teacher, 10 years of experience, Croatia)

The quotation above shows the belief that the state and school level processes should be aligned and communicates a sense of disorder, because they are, in fact, not aligned. Although teachers felt they needed to compensate for this, there were no consequences if they did not. If they did try to include the Matura into the teaching curriculum, then they may get a commendation at school, but nothing else. There were also no sanctions for those that did not incorporate the standards. Hence, in a certain way, the accountability was low, as well as the incentives to do anything. This is quite contrary to the type of neoliberal thinking where outcomes are related to the consequences for teachers or for students. In Croatia and Serbia this was not the case. Thus, there is a sense of thinking about education as a public good, and not something where one carries individual responsibility for it. There is also the idea that all schools should be provided with equal financial resources before they can even enter the competition.

The standards should be the same in the whole country, they should be determined by the Ministry of Education and we, the teachers, should comply with the standards for the better achievement of students (Biology teacher, 5 years of experience, Serbia)

The data gathered in our two research studies correspond to Minina's (2014: 20) explanation about the perception of standards as a tool that should ensure education as a public good and the statement that the state has an obligation to distribute it "fairly, uniformly, and free-of-charge" in the postSoviet Russia. Consequently, teachers approach standards as a failed policy initiative that can hardly influence, let alone improve their classroom practice, but as an initiative nonetheless that requires them to do more administrative work.

Standards as the ways of overcoming some shortfalls in professional identity (e.g. in marking students)

Our two research studies showed that some teachers from the sample perceived standards as a way of overcoming some shortfalls in their professional identity, especially related to the process of marking students. 
Teachers were unsure as to how to mark students, so the prospect of standards gave them more guidance and reassurance. The participants of our two studies explained that, after the introduction of standards, they could more easily explain to students and parents what was expected for different marks, that there were different levels of achievement which can motivate students who want to have a better mark since they could find out what they should learn for every mark and at which level. At the same time, it was easier to compare the marks between students from other schools when educational standards are defined at national level.

I think it's good that now we have standards. And without standards we used to work in similar frames, but now it is a little clearer. Now this is more concrete for the children, they know what is expected for which grade. It is similar with parents - they know what to expect, that they shouldn't hope for an underserved grade, but also to motivate students to learn more and to have defined levels of achievement. (Physical Education teacher, 25 years of experience, Serbia)

Many teachers think, especially in primary schools, but also here in secondary - everyone wants to see good grades, so why create problems and give bad grades when nobody would complain if $80 \%$ of the class had the highest grade! Nobody calls the inspection for the surplus of fives (the highest grade). But if you want to teach something, then it's good to have the Matura now, so we can say: this is the grade you will get at the Matura. We can explain to parents better how we assign grades.(Biology teacher, 31 years of experience, Croatia)

The results collected in our research studies are in line with the findings of the study by Malinić, Komlenović and Stanišić (2013) that investigated the expectations of 400 natural sciences teachers in primary schools in Serbia related to the impact of the introduction of the educational standards on the achievement and assessment of students. Namely, more than half of the teachers involved in this study reported they expected that the introduction of standards would make the process of assessment easier and that "the implementation of the educational standards will mostly limit the possibilities of subjective assessments" (Malinić et al. 2013: 577). In addition, teachers from the same sample realized their professional benefit related to the standards in the selection of teaching materials, their professional development and organization of work (Komlenović, Malinić\&Stanišić, 2014: 402). In the above-mentioned RANON study, several teachers from the sample also pointed out that they found standards as a useful tool that would help them to improve the way of grading students (Radišić, 2012). 


\section{Concluding remarks}

Standards may have begun within a neoliberal rhetoric, as something that should measure learning to serve the country economies, but we hope to have demonstrated that they do not necessarily always serve the economic purposes. The way in which the Croatian and Serbian governments introduced standards has been different from that of many other countries. Naturally, the way in which the Serbian and Croatian teachers that participated in our two research studies responded to them has also been different. While the notion of standards evokes the ideas of accountability and testing and a loss of the role of the government in education in the countries such as the UK and the USA, in Serbia and Croatia standards are still very much part and parcel of a public image of education, where the state still plays a major role. While there are plenty of differences in education between Croatia and Serbia, this paper has focused on similarities with the globally travelling reforms, such as the standards-based education. For that reason, it has mostly presented the data in which teachers from Croatia and Serbia expressed similar perspectives in their responses. The aim was to make the argument that standards are seen to belong within the purview of public education, rather than something that fundamentally transforms public education towards a more market- and competition-based approach.

One of the reasons for these responses may be the Croatian and Serbian teachers' pre-service training. As some authors suggest, the pre-service training in these countries does not leave teachers feeling competent enough to work in school because the training makes them experts in a specific field, e.g. Mathematics, rather than confident in leading and facilitating students' learning (cf. Radišić et al., 2012: 232). This is in line with the idea that teachers in Serbia and Croatia do not consider themselves as potential leaders in the process of changing contemporary educational practices (Pantić \& Čekić Marković, 2012: 37; Vranješević \& Vujisić Živković, 2013: 590). Additionally, relevant scholars point out that it is extremely important to take into consideration teachers' opinions about the suggested actions and reforms, because, that way, reforms become more realistic and easier to implement in ever-day school practice (Stanković et al., 2012; Stanković et al., 2013).

We have shown how the notion of 'standards' has watered down in the interchange between teachers and administrators and how a new meaning of standards was used to position and re-position the policy and administrative stances in education, rather than revolutionize education as one may know it. All this was underpinned by a shared belief (among teachers and administrators) in a perfect procedure and a perfect alignment of education policy.

We are saying that, in spite of the fact that supranational organizations decide what is valuable in education today, the local adaptations of those values may look completely different from what supranational organizations 
have envisaged. Perhaps the vision of 'standards' in the countries like Croatia and Serbia can help us to see some value in standards again, without completely having to dismiss them in international education.

\section{References}

World Bank. (2017). International Comparison Database. Avalilable at https://data. worldbank.org/indicator/NY.GNP.PCAP.CD. Accessed November 2018.

Human Development Index. (2018). Available at http://www.hdr.undp.org/en/2018update. Accessed December 2018.

Bain, O. (2010). Education after the fall of the Berlin Wall: The end of history or the beginning of histories. In I. Silova (Ed.), Post-socialism is Not Dead: (re)reading the Global in Comparative Education. Bingley: Emerad. pp. 25-57; Retrieved from https://books.google.hr/books?id=K6xT2XMWy2gC\&pg=PA4\&lpg=PA4\&dq=po st+socialism+is+not+dead+pdf+bain ....

Baird, J. (2013). The currency of assessments. Assessment in Education: Principles, Policy and Practice, 20(2), 147-149. doi:10.1080/0969594x.2013.787782

Ball, S.J. (2003). The teacher's soul and the terrors of performativity. Journal of Education Policy, 18(2), 215-228. doi:10.1080/0268093022000043065

Ball, S.J. (2015). What is policy? 21 years later: reflections on the possibilities of policy research. Discourse: Studies in the Cultural Politics of Education, 36(3), 306-313. doi:10.1080/01596306.2015.1015279

Barber, M. (2004). The Virtue of Accountability: System Redesign, Inspection, and Incentives in the Era of Informed Professionalism. Journal of Education, 185(1), 7-38. doi:10.1177/002205740518500102

Berry, R., \& Adamson, B. (2011). Assessment Reform in Education. New York: Springer.

Black, P., \& Wiliam, D. (1998). Assessment and Classroom Learning. Assessment in Education:Principles, Policyand Practice, 5(1),7-74.doi:10.1080/0969595980050102

Broadfoot, P. (1996). Education, Assessment and Society. Bristol: Open University Press.

Broadfoot, P. (2000). Comparative Education for the 21st Century: Retrospect and prospect. Comparative Education, 36(3), 357-371. doi:10.1080/03050060050129036

Dull, L.J. (2012). Teaching for Humanity in a Neoliberal World: Visions of Education in Serbia. Comparative Education Review, 56(3), 511-533. doi:10.1086/664993

Guest, G., MacQueen, K., \& Namey, E. (2012). Applied Thematic Analysis. London: SAGE Publications. doi:10.4135/9781483384436

Gunzenhauser, M.G. (2003). High-Stakes Testing and the Default Philosophy of Education. Theory Into Practice, 42(1), 51-58. doi:10.1353/tip.2003.0007

Hargreaves, A., Earl, L., Moore, S., \& Manning, S. (2001). Learning to change: Teaching beyond education and standards. San Francisco: Jossey-Bass..

Hebib, E. i Spasenović, V. (2011). Školski sistem Srbije i pravci razvoja. Pedagogija, 66 (3), 373-383.

Hursh, D. (2005). Neo-Liberalism, Markets and Accountability: Transforming Education and Undermining Democracy in the United States and England. Policy Futures in Education, 3(1), 3-15. doi:10.2304/pfie.2005.3.1.6 
Ivić, I. (1996). A draft of a necessary curriculum theory. In G. Zindović-Vukadinović \& S. Krnjajić (Eds.), Towards a modern learner - centered curriculum. Belgrade: Institute for Educational Research - UNESCO - UNICEEF.

Klieme, E., Avenarius, H., Blum, W., Döbrich, P., Gruber, H., Prenzel, M., . . Vollmer, H. (2003). The development of national educational standards. An expertise. Berlin: Bundesministerium für Bildung und Forschung/Federal Ministry of Education and Research (BMBF). Publications and Website Division D-11055.

Kovač, C.T., \& Levkov, L.J. (2002). Kvalitetno obrazovanje za sve, Put ka razvijenom društvu / Quality Education for All, Way Toward a Developed Society. Beograd: Ministarstvo prosvete I sporta Republike Srbije. [ [Kovács-Cerović, Tünde and Levkov, Ljiljana (Eds); Belgrade: Ministry of Education and Sports Republic of Serbia.].

Lim, C.P. (2007). Effective integration of ICT in Singapore schools: Pedagogical and policy implications. Educational Technology Research and Development, 55(1), 83-116. doi:10.1007/s11423-006-9025-2

Minina, E. (2014). "Why Doesn't the Telephone Ring? Reform of Educational Standards in Russia" Still an Issue? Approaching and Challenging Post-Socialist and Post-authoritarian Education: Difficulties, Routines and Innovations of Empirical Research. Inter Disciplines: Journal of History and Sociology, 5 (2); 1-44.

Maksimović, A. (2016). Teachers' views of student achievement standards / Standardi postignuća učenika iz perspektive nastavnika. Nastava $i$ vaspitanje, 65(2), 279296. doi:10.5937/nasvas $1602279 \mathrm{~m}$

Merriam, S.B. (1998). Qualitative research and case study applications in education. San Francisco: Jossey-Bass..

MoSES. (2005). Education Sector Development Plan 2005-2010. Zagreb. Retrieved from https://mzo.hr/sites/default/files/migrated/education-sector-developmentplan-2005-2010.pdf.

Oliver-Hoyo, M., \& Allen, D. (2006). The Use of Triangulation Methods in Qualitative Educational Research. Journal of College Science Teaching, 35 (4); 42-47.

Ministarstvo prosvete i sporta. (2003). Opšte osnove školskog programa / The national core curriculum for general education. Beograd.

Ministarstvo prosvete Republike Srbije,, \& -Zavod za vrednovanje kvaliteta obrazovanja I vaspitanja, (2009). Obrazovni standardi za kraj obaveznog obrazovanja / Educational standards for the end of compulsory education. Beograd.

Ministarstvo prosvete Republike Srbije,, \& -Zavod za vrednovanje kvaliteta obrazovanja I vaspitanja, (2011). Opšti standardi postignuća - obrazovni standardi za kraj prvog ciklusa obrazovanja / General Standards of Achievement for the first cycle of education. Beograd.

Pravilnik o opštim standardima postignuća za kraj opšteg srednjeg obrazovanja i srednjeg stručnog obrazovanja u delu opšteobrazovnih predmeta / The Rulebook on .... Službeni glasnik Republike Srbije / Official Gazette of the Republic of Serbia, (2013). br. 117 / no. 117.

Radišić, J., Raković, J., Pantić, N., Marković, J., Maksimović, A., \& Marković, M. (2012). Teachers as proponents and opponents of education reforms - the case of Serbia. In J. Madalinska-Michalak, H. Niemi, \& S. Chong (Eds.), Research, Policy and Practice in Teacher Education in Europe. Lodz: University of Lodz. 223-241. 
Rado, P. (2010). Governing Decentralized Education Systems: Systemic Change in South Eastern Europe. Budapest: Open Society Foundations.

Radunović, D. (2007). Predlog obrazovnih standarda na kraju obaveznog obrazovanja $\mathrm{u}$ Srbiji / Proposal of educational standards at the end of compulsory education in Serbia. In Z. Grac (Ed.), Istraživanje obrazovanja $i$ formulisanje obrazovnih politika. Beograd: Centar sa obrazovne politike / Research on Education and Formulation of Educational Policies. Beograd: Centar sa obrazovne politike. [Belgrade: Centre for Education Policy].

Reay, D. (2012). "We never get a fair chance": Working class experiences of education in the twenty-first century. In W. Atkinson, S. Roberts, \& M. Savage (Eds.), Class Inequality and Austerity in Britain: Power, Difference and Suffering. Houndmills: Palgrave Macmillan. (pp. 33-50). Doi:10.1057/9781137016386.0006.

Rizvi,, \& Lingard, (2010). Globalizing education policy. Oxon: Routledge.

Robertson, S.L. (2012). Teachers' work, denationalisation, and transformations in the field of symbolic control: A comparative account. University of Bristol - Centre for Globalisation, Education and Societies. Retrieved from http://susanleerobertson.com/publications.

Sharma, P. (2015). Standards-based Assessments in the Classroom: A Feasible Approach to Improving the Quality of Students' Learning. Contemporary Education Dialogue, 12(1), 6-30. doi:10.1177/0973184914556864

Silova, I., \& Steiner-Khamsi, G. (2008). How NGOs React. In I. Silova \& G. SteinerKhamsi (Eds.), How NGOs react. Bloomfield: Kumarian. pp. 1-41.

Silova, I., \& Brehm, W.C. (2013). The Shifting Boundaries of Teacher Professionalism. In T. Seddon \& J.S. Levin (Eds.), World Yearbook of Education. Oxon: Routledge. (pp. 55-74).

Silova, I., \& Eklof, B. (2013). Education in Eastern and Central Europe: Re-Thinking Post-Socialism in the Context of Globalisation. In R.F. Arnove \& C.A. Torres (Eds.), Comparative Education: The Dialectic between the global and the local. New York: Rowman and Littlefield. pp. 379-402; 4th ed..

Smith, L.A., Anderson, V., \& Blanch, K. (2016). Five beginning teachers' reflections on enacting New Zealand's national standards. Teaching and Teacher Education, 54, 107-116. doi:10.1016/j.tate.2015.11.014

Sobe, N.W. (2006). U.S. Comparative Education Research on Yugoslav Education in the 1950s and 1960s. European Education, 38(4), 44-64. doi:10.2753/eue1056-4934380403

Stobart, G. (2008). Testing times: The uses and abuses of assessment. Informa UK Limited. doi:10.4324/9780203930502

Spady, W. (1998). Paradigm lost: Reclaiming America's educational future. Arlington, VA: American Association of School Administrators.

Stanković, D. (2011). Obrazovne promene u Srbiji (2000-2010) / Educational Changes in Serbia (2000-2010). In M. Vujačić, J. Pavlović, D. Stanković, V. Džinović, \& I. Đerić (Eds.), Predstave o obrazovnim promenama u Srbiji. Refleksije o prošlosti, vizije budućnosti / Educational Changes in Serbia. Reflections on the past, the vision of the future. Belgrade: Institut za pedagoška istraživanja / Institute for Pedagogical Research. (pp. 41-62).

Steiner-Khamsi, G., \& ed., (2004). The global politics of educational borrowing and lending. Teachers College Press. 
Steiner-Khamsi, G. (2012). Understanding policy borrowing and lending. In: G. Steiner Khamsi \& F. Waldow (Eds.), World Yearbook of Education 2012. New York: Routledge. doi:10.4324/9780203137628

Steiner-Khamsi, G., Silova, I., \& Johnson, E.M. (2006). Neoliberalism liberally applied Educational policy borrowing in Central Asia. In J. Ozga, T. Seddon, \& T.S. Popkewitz (Eds.), World Yearbook of Education Education Research and Policy: Steering the Knowledge-based Economy. Oxon: Routledge. (pp. 217-245). 2006.

Steiner-Khamsi, G., Stolpe, I., Steiner-Khamsi, G., \& Stolpe, I. (2006). Educational Import in Mongolia: A Historical Perspective. In Educational Import. (pp. 23-49). New York: Springer Science and Business Media LLC. doi:10.1057/9781403982971_2

Volante, L., \& Earl, L. (2015). Standards, accountability, and student assessment systems. Education Canada, 55(2). Retrieved from http://www. cea-ace.ca/educationcanada/article/standards-accountability-and-studentassessment- systems.

Wyatt-Smith, C., \& Cumming, J. (2009). Educational Assessment in the 21st Century. In C. Wyatt-Smith \& J.J. Cumming (Eds.), . Dordrecht: Springer Science and Business Media LLC. doi:10.1007/978-1-4020-9964-9

\section{Mišljenje nastavnika o implementaciji obrazovnih standarda u Srbiji i Hrvatskoj}

\section{Aleksandra S Maksimović}

Visoka skola strukovnih studija za vaspitače, Šabac

\section{Ivana Ćosić}

\section{Zagreb, Republika Hrvatska}

Cilj ovog rada je da uporedimo kako nastavnici u Srbiji i Hrvatskoj shvataju koncepciju obrazovnih standarda i njihovo uvođenje u obrazovnu politiku i školsku praksu. Dalje, ovaj članak ispituje perspketive nastavnika o obrazovnim standardima u osnovnim i srednjim školama u Srbiji i Hrvatskoj i upoređuje ih sa razumevanjem ovog koncepta od strane nastavnika u drugim zemljama. Primenjen je kvalitativni metodološki pristup, sprovedeni su individualni i fokus-grupni intervjui sa nastavnicima, kao i tematska analiza prikupljenih podataka. Intervjui su realizovani tokom izrade dve doktorske disertacije. Uzorak čini 101 nastavnik, od toga su 57 nastavnici u osnovnim školama u Srbiji, a 44 su nastavnici u srednjim školama u Hrvatskoj. Rezultati pokazuju da nastavnici u ovim zemljama imaju vrlo slične doživljaje kada je u pitanju implementacija obrazovnih standarda u njihovim zemljama i mi smo ih prikazali prateći tri međusobno povezane teme: 1) nepoverenje u obrazovnu administraciju; 2) shvatanje obrazovanja kao javnog dobra i 3) standardi kao način prevazilaženja određenih nedostataka u profesionalnom identitetu.

Ključne reči: obrazovni standardi, nastavnici, Srbija, Hrvatska 